ADLFI. Archéologie de la France -

INFORMATIONS

Informations

une revue Gallia

Midi-Pyrénées | 1991

\title{
Canton de Cornus
}

\section{(2) OpenEdition \\ Journals}

Édition électronique

URL : http://journals.openedition.org/adlfi/10479

ISSN : 2114-0502

Éditeur

Ministère de la culture

Référence électronique

"Canton de Cornus », ADLFI. Archéologie de la France - Informations [En ligne], Midi-Pyrénées, mis en ligne le 01 mars 1997, consulté le 21 avril 2019. URL : http://journals.openedition.org/adlfi/10479

Ce document a été généré automatiquement le 21 avril 2019

(c) Ministère de la Culture et de la Communication, CNRS 


\section{Canton de Cornus}

Date de l'opération : 1991 (PC)

Inventeur(s) : Roux Caroline

1 Une recherche basée sur l'étude des sources écrites a été à l'origine d'un travail portant sur la formation de l'habitat entre le XII ${ }^{e} s$. et le $\mathrm{XV}^{\mathrm{e}} \mathrm{s}$. sur neuf communes du sud de l'Aveyron, couvrant un espace de 33000 ha : Le Clapier, Cornus, Lapanousse-de-Cernon, Marnhagues-et-Latour, Montpaon, Saint-Beaulize, Saint-Jean-et-Saint-Paul, SainteEulalie-de-Cernon et Viala-du-Pas-de-Jaux.

2 Ce travail essentiellement bibliographique, complété par quelques prospections au sol, a été l'occasion de replacer «l'histoire » de ce secteur géographique dans un contexte où l'habitat se concentre, le castrum devient village et le réseau paroissial se fixe. Ainsi, l'abbaye de Nonenque disposait de cinq granges dans le canton, citées dès 1177 et jusqu'en 1334.

3 À Caussanuéjouls, la grange cistercienne, longue d'une centaine de mètres, comprend quinze travées à contreforts et une chapelle intégrée dans le corps principal. Trois maisons templières sont encore attestées à Sainte-Eulalie-de-Cernon et au Viala-du-Pasde-Jaux, à Gals et Fraissinel. Parmi les seize églises paroissiales du canton, quinze sont des prieurés et déterminent bien souvent la concentration de l'habitat comme à SainteEulalie, Saint-Beaulize, Cornus, Le Clapier et Lapanouse-de-Cernon qui voient la croissance du hameau se développer en village entouré d'une enceinte (entre le XII ${ }^{\mathrm{e}}$ s. et le XVes.).

4 Sur le plan monumental, restent encore à signaler une tour de guet (tour des Aiguillons) qui, dès le XII ${ }^{\mathrm{e}}$ s.protégeait Cornus et un grenier fortifié, et la tour défensive-grenier à grain du Viala-du-Pas-de-Jaux, construite vers 1430 par les Hospitaliers. 
INDEX

Index chronologique : Moyen Âge*

Index géographique : Midi-Pyrénées, Aveyron (12), Cornus

operation Projet collectif de recherche (PCR) 